УДК $347.6: 001.78: 37.018 .5: 372$

DOI: $10.15330 /$ esu. $1.134-138$
Неллі Лисенко,

доктор педагогічних наук, професор,

ДВНЗ "Прикарпатський національний університет

імені Василя Стефаника"

(м. Івано-Франківськ, Україна)

Nelli Lysenko,

Doctor of pedagogic sciences, Professor,

Vasyl Stefanyk Precarpathian national university

(Ivano-Frankivsk, Ukraine)

doshkilnaosvita@i.ua

\title{
СУЧАСНІ ПІДХОДИ ДО ЕКОЛОГІЧНОГО ВИХОВАННЯ ДІТЕЙ ДОШКІЛЬНОГО ВІКУ У РУСЛІ КОНЩЕПЩЇ̈ ЗБАЛАНСОВАНОГО РОЗВИТКУ
}

\section{MODERN APPROACHES TO ENVIRONMENTAL EDUCATION OF PRESCHOOL AGE CHILDREN IN LINE WITH THE CONCEPT OF BALANCED DEVELOPMENT}

У статті розглянуто актуальні підходи до організачії екологічної освіти дітей дочкільного віку, представлено етапи формування екологічної свідомості у сенситивному періоді особистісного зростания дітей.

Ключові слова: екологічне виховання, діти дошкільного віку, збалансований розвиток, природне довкілля, екологічна свідомість.

In the report "Our Common Future" by Gro Harlem Brundtland (at the time the Prime Minister of Norway) it was raised a number of topical issues that had a positive impact on the Earth Summit in Rio de Janeiro in 1992 and the Third UN Conference on problems of environment in Johannesburg (South Africa) in 2002.

As a result of the work of the Brundtland Commission, significant adjustments have been put on the agenda of educational institutions from different countries of the world, and the importance of strengthening the educational and methodological support of environmental education at all levels has been emphasized. The common guideline for the steady implementation was the need for permanent formulation with scientific substantiation of innovative, concrete and realistic actions of all participants of international cooperation in the field of environmental protection.

It is about forming the ecological consciousness of people from the youngest age to ensure adult readiness for eradicate destroyed ecosystems to prevent harmful effects on the planet's ecological balance as soon as possible.

Preparation for an active life position in the context of our problem is initiated by a modern preschool institution. The dependence of the paces of development of civilization on the attained level of education of all age categories of society is determined by the personal qualities and abilities of each citizen and, above all, the growing generations.

It is known that the level of formation of environmental consciousness is based on the achievements of the individual in the preschool years. Successful shaping of the environmental awareness of preschoolers is not possible without their mastery of knowledge and the awareness of the importance of the laws by which the expected knowledge can be obtained. Therefore, the deeper and more versatile the awareness of children with the natural environment, the greater is the teacher's ability to form systemic perceptions and knowledge about the natural environment as a whole. In the context of the above, the concept of "ecological consciousness" appears as complex: it is the teaching of methods, techniques, as well as the forming of skills to know the natural environment in all its dimensions, guided by the undeniable priority of personal moralvalue orientations that stimulate active counteraction to irrational nature management, however in everyday life. 
Forming of ecological consciousness is a long and complicated process, and its manifestations clearly follow in the real actions and attitudes of children to nature.

Key words: ecological education, preschool age children, balanced development, natural environment, ecological consciousness.

Постановка проблеми. У триєдиній меті концепції збалансованого (сталого) розвитку чільне місце посідає збереження природного довкілля. Уперше до такої складової вдалися на Всесвітній Концепції ООН із проблем довкілля людини (Стокгольм, 1972 р.) Актуалізація різних аспектів екологічної проблематики, втім, i кооперація міжнародних механізмів задля iї успішного вирішення набула продовження у низці подальших зібрань дослідників - представників різних країн світу і вже невдовзі, у 1980 році, Міжнародна спільнота охорони природи (МСОП) оприлюднила "Всесвітню стратегію охорони природи (ВСОП) із обгрунтованою концепцією щодо неподільної єдності між збереженням природного довкілля людини та розвитком суспільства, в якому вона життєдіє. Згодом, у 1987 році, уже під час звіту Міжнародної комісії із проблем довкілля та розвитку, який підготували під керівництвом Г.Х.Брунтланд поняття “збалансований” (сталий) розвиток набуло поширення у різноманітних сферах функціонування соціуму, втім, i в соціальній, до якої належить освіта.

У доповіді “Наше спільне майбутнє" Гру Харлем Брунтланд (на той час прем’єр-міністр Норвегіï) порушено низку актуальних проблем, які позитивно вплинули на Самміт Землі у Ріо-де-Женейро у 1992 році та на III-тю Конференцію ООН із проблем навколишнього середовища в Йоханнесбурзі (Південна Африка) у 2002 році.

Отож мета статті полягає у тому, щоб довести вплив ідей, які були презентовані на зазначених вище форумах на стан теорії та практики організації екологічної освіти, починаючи із дошкілля на формальному та неформальному рівнях, а також їхнє спрямування у глобальне русло задля багатонаціонального кооперування зусиль теоретиків i практиків зі сфери охорони i збереження природного довкілля.

Аналіз останніх досліджень. 3 метою успішного розв'язання насущних проблем у галузі екологічної освіти, забезпечення оптимального балансу між добробутом людини і станом природи, ученими (М.Бауер, І.Дедю, П.Дювіньо, А.Захлєбней, І.Зверєв, В.Шинкарчук започатковуються активні дослідження різних напрямів забезпечення екологічної освіти зростаючих поколінь, утім починаючи із дошкільного віку ( І.Бех, Г.Бєлєнька, Н.Лисенко, З.Плюхій, Н.Яролева).

Виклад основного змісту. На наш погляд, позитивним зрушенням слід визнати дискусії щодо правомірності твердження, яке було ухвалене на Стокгольмській конференції (1972р.) про субординацію факторів у взаємодії між навколишнім середовищем і людиною, а саме - людина повинна спрямувати свою діяльність із пріоритету споживач природних ресурсів у пріоритет їх економний та раціональний користувач. Саме згідно концепції Комісії Брунтланд, навколишнє середовище уже постає тим місцем, в якому ми живемо; натомість розвиток - це все, що ми робимо і зробимо задля покрашення свого життя у цьому середовиші. Відповідно, ці поняття трактуються як неподільні у своєму збалансованому функціонуванні. Унаслідок діяльності Комісії Брунтланд на порядок денний освітніх інституцій різних країн світу винесено для обговорення суттєві корективи, а також наголошено на важливості посилення навчально-методичного супроводу екологічної освіти на всіх 
iii рівнях. Спільною настановою для неухильного виконання виголошено необхідність перманентного формулювання із науковим обгрунтуванням інноваційних, конкретних та реалістичних дій всіх учасників міжнародної співпраці у справі охорони природного довкілля. Саме вони взмозі вплинути на його стан включно із зусиллями громадських і освітніх інституцій.

Упродовж останніх 20-ти років охорона природного довкілля зберігає свій пріоритет у низці освітніх проблем, починаючи із закладів для дітей дошкільного віку.

Мовиться про формування екологічної свідомості громадян із наймолодшого віку для того, щоб якомога швидше забезпечити готовність дорослого населення до оновлення зруйнованих екосистем задля попередження згубного впливу на екологічний баланс планети. Лише активна відновлювальна діяльність усіх землян взмозі забезпечити позитивні зрушення у майбутньому, стабілізувати планетарну екосистему з їі оптимальними параметрами для життєдіяльності людини.

Радикальні соціокультурні зміни, стрімке зростання темпів інтелектуалізації всіх верств, починаючи від дітей дошкільного віку, комп'ютеризація не лише технологічних, а й освітніх процесів поглиблюють кризу в міжособистісних взаємовідносинах, обмежуючи поле безпосереднього комунікування. Таким чином, можемо стверджувати про необхідність посилення впливу і ролі особистості в усіх сферах іï життєдіяльності. Підготовку до активної життєвої позиції у контексті порушеної нами проблеми започатковує сучасний заклад дошкільної освіти. Залежність темпів розвитку цивілізації від досягнутого рівня освіченості всіх вікових категорій суспільства детермінована особистісними якостями і здібностями кожного громадянина i, передусім, зростаючих поколінь.

Екологічна освіта в Україні, на жаль, здійснюється не завжди на належному рівні у системі формальної та неформальному рівні. Природньо, що такий стан справ обумовлений недостатнім фінансуванням і матеріальним забезпеченням навчальновиховного процесу. Дослідження останніх років наочно демонструють несприятливі тенденції в організації та плануванні ділянки ЗДО, обладнанні кутків і кімнат природи, умов та обладнання для пошуково-дослідницької діяльності з рослинами i тваринами. Як відомо, рівень сформованості екологічної свідомості грунтується на здобутках особистості в дошкільні роки. Забезпечення успішного формування екологічної свідомості дошкільників не можливе без опанування ними знаннями i усвідомлення важливості законів, якими можна здобути очікувані знання. Отож, чим глибшою i різностороннішою $є$ обізнаність дітей із природним довкіллям, тим більшими є можливості педагога формувати системні уявлення і знання про природне довкілля загалом. У контексті зазначеного, поняття “екологічна свідомість" постає як комплексне: це навчання методів, прийомів, а також формування навичок пізнавати природне довкілля у всіх його вимірах, керуючись беззаперечним пріоритетом особистісних морально-ціннісних орієнтацій, які стимулюють активну протидію нераціональному природокористуванню, втім і в побуті. Залучення дітей в розрахунки із використання родиною природніх ресурсів (вода, світло, продукти харчування рослинного і тваринного виробництва, засоби побутової хімії та ін.) ініціює зміцнення особистісної відповідальності за природне довкілля, додержання традицій природокористування із урахуванням культурних цінностей, традицій, звичаїв і обрядів певної територіальної чи етнічної громади.

Організація i керівництво діяльністю дітей дошкільного віку на етапі формування основ екологічної свідомості повинна бути спрямована на їхню 
самостійність в ухвалі рішень (що і як зробити?) і в доборі засобів успішного досягнення сформульованої мети. Важливо брати до уваги, що дітям досить важко бути абсолютно самостійними, отож, вкрай необхідним прийомом моделювання навчальних ситуацій, в яких вони виявляють самостійність, повинно стати створення відчуття безпеки та їх захисту дорослими у компромісних ситуаціях, тобто забезпечити баланс між самостійністю і безпекою. Критерієм оптимального балансу між активністю дитини та іiі самостійністю у пошуково-дослідницькій діяльності можна визнати мотивацію. Саме мотивація демонструє рівень зацікавленості діяльністю, об'єктом чи об'єктами пізнання, добором необхідних дій, готовністю їх виконати самостійно. Мотивація пошуково-дослідницької діяльності охоплює низку етапів, це: байдуже сприйняття об'єкта 3 ініціативи виховательки (вона спонукає до того, щоб дитина розглянула, обстежила, звернула увагу); зовнішня мотивація (дитина хоче розглянути самостійно запропонований об'єкт). На запитання виховательки “А як ти хочеш розглянути...?”, “Для чого ти хочеш розглянути...?”, “Що ти хочеш побачити...?" та ін., дитина виявить зовнішню мотивацію ум такій відповіді: “Я хочу розглянути..., а що там шумить? Чи що $є$ там усередині? тощо. Завдання виховательки полягає в тому, щоб такий прояв мотивації перевести у іiі складнішу i продуктивнішу форму - внутрішню мотивацію. Саме внутрішньо мотивовані діти будуть досліджувати, пізнавати тому, що в цьому полягає їхня потреба: вони хочуть знати, оскільки для них це важливо. 3 цього приводу вони виявляють позитивні почуття, проектують подальші дії, висловлюють припущення, складніші завдання вони сприймають спокійно та з емоційним захопленням.

Формування екологічної свідомості - довготривалий і складний процес, а іiі прояви чітко прослідковують в реальних діях і ставленні дітей до природи. Для цього розглянемо один із варіантів прогнозування та реалізації пошуководослідницької діяльності.

На I підготовчому етапі завдання виховательки полягає у тому, щоб викликати максимальне зацікавлення (симпатію) дітей до об'єкта чи явища, з яким передбачається взаємодія. Зацікавлення стимулювати запитаннями і пропозиціями аж до того моменту, коли діти (дитина) захочуть самостійно пізнати чи взаємодіяти; виявлять бажання навчитися робити чи виконувати дії, які поки-що виконує вихователька; заклик “Я хочу!” (“Ми хочемо!") як прояв внутрішньої мотивації дозволяє перейти до II етапу. Саме тут акцентують увагу дітей на тому, що лише вони взмозі пізнати (розглянути, перевірити, переконатися, довести) сутність об'єкта чи явища. Цей етап емоційно насичений позитивною самооцінкою кожної дитини. На III-му етапі всі учасники обговорюють ситуацію за такими орієнтовними запитаннями. А саме:

- Що ми хочемо зробити, щоб вирішити нашу проблему?

- Що ми будемо для цього робити спільно?

- Що буде робити кожен із нам?

- Як ми будемо це робити?

- Що для цього потрібно кожному з нас?

- Які умови треба створити, щоб успішно виконати завдання?

- Якими іншими способами (діями) можна виконати наше завдання (розв'язати проблему)?

- Що треба зробити, щоб вирішити проблему спільно?

- Як ми дізнаємося про те, шо досягли очікуваного результату? та ін. 
Висновки. На основному етапі вирішення проблеми вихователька має унікальну можливість не лише зреалізувати повний обсяг спрогнозованих завдань i досягти очікуваної мети (можливо, відтермінувати іiі на певний період, якщо дослід довготривалий), а й діагностувати кожну дитину на основі ії ж дій, прояву почуттів, поведінки у товаристві однолітків і т.д. Діагностувати, насамперед, рівень мотивації кожної дитини; ієрархію особистісних цінностей; потреби; способи взаємодії; ролі, які дитина готова брати на себе у групових (колективних) видах діяльності. Все, що взмозі діагностувати вихователька, $є$ цінним 3 погляду формування екологічної свідомості, оскільки діти взаємодіють із об'єктами і явищами реальної природи. Елементи самодіагностики (самооцінки), які слід практикувати в старшому дошкільному віці, розглядаємо важливими для формування самосвідомості та особистісного поступу кожного вихованця у період його шкільного навчання.

\section{Література}

1. Бех І.Д. Виховання особистості : у 2 кн. - Кн.1:Особистісно-орієнтовний підхід : теоретикотехнологічні засади/ І.Д. Бех. К.: Либідь, 2003.- 280 с.

2. Бєлєнька Г.В. Експериментування - крок до пізнання/ Г.В. Бєлєнька//Дошкільне виховання 2007. - №5.- c. 7-10

3. Всесвітня стратегія охорони природи: https://school.home-task.com/vsesvitnya-strategiya-oxoroniprirodi/

4. Екологічна політика//Філософський енциклопедичний словник/ В.І. Шинкарук (голова редколегії) та ін.- Київ: Абрис, 2002. - 742 с.

5. Екологічна політика та збалансований розвиток - Всеукраїнська екологічна ліга

6. Свропейське право навколишнього середовища: Навч.посіб./М.М. Микієвич, Н.І. Андрусевич, М.О. Будякова; Львів.нац.університет ім. І.Ф. Франка. - Л., 2004.- 255 с.

7. Наше спільне майбутнє. Звіт Міжнародної комісії з довкілля.

\section{References}

1. Bekh I.D. Vykhovannia osobystosti : u $2 \mathrm{kn}$. - Kn.1:Osobystisno-oriientovnyi pidkhid : teoretykotekhnolohichni zasady/ I.D. Bekh. K.: Lybid, 2003.- 280 s.

2. Bielienka H.V. Eksperymentuvannia - krok do piznannia/ H.V. Bielienka//Doshkilne vykhovannia 2007. - №5.- s. 7-10

3. Vsesvitnia stratehiia okhorony pryrody: https://school.home-task.com/vsesvitnya-strategiya-oxoroniprirodi/

4. Ekolohichna polityka//Filosofskyi entsyklopedychnyi slovnyk/ V.I. Shynkaruk (holova redkolehii) ta in.- Kyiv: Abrys, 2002. - 742 s.

5. Ekolohichna polityka ta zbalansovanyi rozvytok - Vseukrainska ekolohichna liha

6. Ievropeiske pravo navkolyshnoho seredovyshcha: Navch.posib./M.M. Mykiievych , N.I. Andrusevych, M.O. Budiakova; Lviv.nats.universytet im. I.F. Franka. - L., 2004.- 255 s.

7. Nashe spilne maibutnie. Zvit Mizhnarodnoi komisii z dovkillia.

Одержано статтю: 24.10 .2019

Прийнято до друку: 15.11.2019 